JURNAL KETAHANAN NASIONAL

P-ISSN: 0853-9340, e-ISSN: 2527-9688

Online sejak 28 Desember 2015 di: http://jurnal.ugm.ac.id/JKN

VOLUME 22

No. 2, 25 Agustus 2016

Halaman 117-136

\title{
PERAN PEMUDA DALAM MENGELOLA KAWASAN EKOWISATA DAN IMPLIKASINYA TERHADAP KETAHANAN MASYARAKAT DESA (Studi tentang Pemuda Pengelola Desa Wisata Kandri, Kecamatan Gunungpati, Kota Semarang, Provinsi Jawa Tengah)
}

\author{
Sri Haryati \\ PW IPPNU Jawa Tengah \\ Email: sriharyatitannas@gmail.com \\ Armaidy Armawi \\ Fakultas Pascasarjana Universitas Gadjah Mada \\ Muhammad Supraja \\ Fakultas Ilmu Sosial dan Politik Universitas Gadjah Mada
}

\begin{abstract}
The influence of globalization had an impact on the youth of today. Social values that became a figure of youth had been eroded by modernization. Reality same was true in a Kandri Tourism Village was located in the Village Kandri, Gunungpati subdistrict, Semarang. Youth who numbered about 900 only 16 youths who participated managing ecotourism. The purpose of research were to determined the role of youth in the management of ecotourism, and examined the implications of the management of ecotourism to the rural communities resilience

This research was qualitative descriptive exposure. The research approach used in the study was a problem that occurs in the community. The collecting of data used observation, interview and documentation.

The results showed that youths'manager had role in the management of ecotourism in the tourist village Kandri with the indicator most prominently the way to the natural area. The shapes of youth's role in this program activities Kandri educational tour namely Farming Tour, Outbound Tour, Goa Kreo Tour, and River Tubing's Tour. The role of youth in the management of the society, especially the youth in the area of ecotourism had not run optimally.

This had implications for the management of the ecotourism area to the rural communities resilience, but it had not run optimally. The impact had positive and negative impacts. The positive impact on the rural communities resilience was the ability to renewed and maintained ecotourism, strengthening of social capital and the rule of law within the citizens, as well as the independence of citizens. The negative impact was the declining ability of youth RW III in selecting the socio-cultural values and social institutions. Therefore, the role of youth Kandri should be increased to preserved the environment so that the sustainability of ecotourism was maintained.
\end{abstract}

Keywords: Role of youth, Ecotourism, Rural Community Resilience

\begin{abstract}
ABSTRAK
Pengaruh arus globalisasi telah memberikan dampak terhadap pemuda masa kini. Nilai-nilai sosial yang menjadi sosok pemuda telah tergerus dengan adanya modernisasi. Realita yang sama juga terjadi di sebuah Desa
\end{abstract}


Wisata Kandri yang berada di Kelurahan Kandri, Kecamatan Gunungpati, Kota Semarang. Pemuda yang berjumlah sekitar 900-an hanya 16 pemuda yang ikut serta mengelola kawasan ekowisata. Tujuan penelitian yaitu untuk mengetahui peran pemuda dalam pengelolaan kawasan ekowisata, dan mengkaji implikasi pengelolaan kawasan ekowisata terhadap ketahanan masyarakat desa.

Penelitian ini merupakan penelitian kualitatif dengan pemaparan secara deskriptif. Pendekatan penelitian yang digunakan yaitu studi pada suatu permasalahan yang terjadi di masyarakat. Pengumpulan data dengan menggunakan observasi, wawancara mendalam, dan studi dokumentasi.

Hasil penelitian menunjukkan, pemuda pengelola berperan dalam mengelola kawasan ekowisata di Desa Wisata Kandri hanya pada indikator ekowisata yaitu perjalanan menuju kawasan alamiah. Bentuk peran tersebut berupa program kegiatan wisata edukasi yang meliputi Wisata Nyawah, Wisata Outbond, Wisata Goa Kreo, dan Wisata River Tubing. Peran pemuda pada pengelolaan masyarakat secara keseluruhan terutama pemuda di kawasan ekowiata belum berjalan secara maksimal.

Pengelolaan kawasan ekowisata ini berimplikasi terhadap ketahanan masyarakat desa, akan tetapi belum mampu berjalan secara maksimal. Pengaruh yang dihasilkan berupa pengaruh positif dan negatif. Pengaruh positif pada ketahanan masyarakat desa yaitu penguatan modal sosial dan ketaatan hukum dalam diri warga, kemampuan memperbaharui dan memelihara kawasan ekowisata, serta kemandirian warga. Pengaruh negatif yang ditimbulkan yaitu menurunnya kemampuan pemuda RW III dalam memilih nilai-nilai sosial budaya dan kelembagaan sosial. Oleh karenanya, peran pemuda pengelola harus ditingkatkan untuk menjaga kelestarian lingkungan sehingga keberlangsungan ekowisata tetap terjaga.

\section{Kata Kunci: Peran pemuda, Ekowisata, Ketahanan Masyarakat Desa}

\section{PENGANTAR}

Perjalanan bangsa Indonesia tidak lepas dari adanya peran para pemuda. Pemuda Indonesia senantiasa menjadi pelopor dan pemimpin bangsa dalam berbagai perjuangan. Sejarah telah menunjukkan bahwa generasi muda senantiasa menjadi tulang punggung terciptanya kemerdekaan bangsa Indonesia. Salah satu Indonesianis terkemuka, Anderson (1991), pernah mengatakan bahwa sejarah Indonesia adalah sejarahnya para pemuda. Pernyataan ini sangat sesuai dengan sejatinya sosok pemuda. Menurut Yudohusodo (1996), pemuda merupakan calon-calon pemimpin yang dinamis, kritis dan kreatif, sekaligus sebagai pembaharu yang bertanggungjawab melalui keikutsertaan dalam mengantarkan bangsa Indonesia menjadi bangsa, pemuda memang perlu menyamakan visi, persepsi dan interpretasi bersama tentang masalah-masalah yang ada dan selanjutnya berusaha untuk mendekatkan serta menyamakan sikap bersama terhadap perkembangan - perkembangan baru tersebut.
Peranan pemuda cukup strategis dalam setiap gerak laju kemajuan bangsa. Semangat pemuda yang dilandasi kesadaran dan tanggung jawab terhadap kehidupan bangsa merupakan kekuatan awal bagi para pemuda. Nasionalisme yang tertanam dalam diri pemuda menjadi kekuatan yang sama baik zaman dahulu maupun saat ini. Rasa kebangsaan yang tertanam akan melawan tantangan dan rintangan yang ada demi terwujudnya kesejahteraan bangsa.

Pemuda berperan aktif sebagai kekuatan moral, kontrol sosial, dan agen perubahan dalam aspek pembangunan nasional. Salah satu peran aktif pemuda sebagai agen perubahan diwujudkan di antaranya dengan mengembangkan kepedulian terhadap lingkungan hidup dan kepedulian terhadap masyarakat. Pengembangan kepeloporan pemuda dilaksanakan untuk mendorong kreativitas, keberanian melakukan terobosan, dan kecepatan mengambil keputusan sesuai dengan arah pembangunan nasional. 
Saat ini, pemuda harus merumuskan kembali strategi perjuangannya. Gerakan yang dilakukan harus memiliki dampak yang lebih dahsyat dalam perubahan sosial. Mengingat tantangan setiap zaman yang berbeda, tentunya pendekatan serta strategi perjuangan masa lalu tidak lagi relevan dengan tantangan masa kini dan masa depan (Mustaqim:2010). Tantangan yang dihadapi pemuda masa kini yaitu bagaimana pemuda dapat mengisi kemerdekaan dengan pembangunan di segala aspek kehidupan. Pemuda dituntut untuk turut serta dalam pembangunan bangsa, baik bagi pemuda yang tinggal di perkotaan maupun pedesaan.

Konsep di atas merupakan gambaran sejatinya sosok pemuda. Realita yang terjadi saat ini, pemuda masih dalam kondisi terjajah. Proses kelabilan dan emosional yang tinggi dalam diri pemuda belum mampu menghadapi pengaruh arus globalisasi yang segala sesuatunya serba moderen, instan, dan canggih. Adanya fasilitas yang tersedia dengan efektif dan efesien telah merubah pola pikir pemuda. Pemuda lebih termakan dengan keadaan serba instan. Proses tersebut telah menggerus nilainilai sosial yang seharusnya dilampaui oleh pemuda dalam berproses di setiap masanya. Sifat sebagai seorang individualis menjadi dampak yang terjadi dalam diri pemuda baik pemuda di perkotaan maupun pedesaan. Kondisi tersebut mengakibatkan pemuda tidak lagi memperdulikan pembangunan di lingkungan sekitar, akan tetapi lebih mementingkan kepentingan pribadi.

Kondisi menurunnya peranan pemuda dalam keikutsertaan membangun lingkungan sekitarnya juga terjadi di Kelurahan Kandri Kecamatan Gunungpati Kota Semarang Provinsi Jawa Tengah. Kelurahan Kandri yang telah diresmikan sebagai desa wisata mempunyai kuantitas pemuda yang cukup banyak. Fakta yang ada, dari sekitar 900-an pemuda hanya 16 pemuda yang ikut serta mengelola kawasan ekowisata tersebut. Kondisi tersebut menjadi keprihatinan bagi perkembangan bangsa pada masa ini dan yang akan datang.

Peneliti merasa perlu mengkaji dan menganalisis adanya fenomena yang terjadi di Desa Wisata Kandri tersebut. Bagaimana proses yang melatarbelakangi adanya fakta tersebut dapat menggambarkan hasil bentuk peran pemuda yang aktif. Adanya bentuk peran yang dilakukan juga bersinggungan dengan masyarakat setempat dan lingkungan sekitarnya. Hal ini sangat menarik pula untuk menganalis bagaimana pengaruhnya terhadap ketahanan masyarakat desa setempat.

Beberapa hasil penelitian seperti penelitian Rosidah (2014) tentang partisipasi pemuda dalam pengembangan kawasan ekowisata dan implikasinya terhadap ketahanan masyarakat desa serta penelitian Hendryantoro (2014) tentang pemberdayaan masyarakat melalui pengembangan desa wisata dan implikasinya terhadap ketahanan sosial budaya telah menunjukkan bahwa pada dasarnya pemuda maupun masyarakat sangat antusias berperan dan berpartisipasi dalam pengembangan desa wisata. Adapun peran dan partisipasi tersebut disebabkan oleh berbagai faktor yang menjadi motivasi tersendiri, akan tetapi dalam pelaksanaanya juga banyak kendala yang dihadapi. Untuk menindaklanjuti hasil penelitian yang dilakukan oleh peneliti sebelumnya, maka peneliti terdorong untuk melakukan penelitian mengenai peran pemuda dalam mengelola kawasan ekowisata dan implikasinya terhadap ketahanan masyarakat 
desa (studi di Desa Wisata Kandri, Kelurahan Kandri, Kecamatan Gunungpati, Kota Semarang, Provinsi Jawa Tengah).

Tujuan dari penelitian ini yaitu (1) mengetahui peran pemuda dalam dalam mengelola kawasan ekowisata di Desa Wisata Kandri; (2) mengkaji implikasi pengelolaan kawasan ekowisata terhadap ketahanan masyarakat desa di Desa Wisata Kandri. Penelitian ini menggunakan beberapa landasan teori sebagai acuan dalam pembahasan penelitian. Landasan teori yang digunakan yaitu teori peran, pemuda ekowisata, dan ketahanan masyarakat desa.

Pertama, menurut Soekanto(1992) peranan (role) merupakan aspek dinamis kedudukan (status).Apabila seseorang melaksanakan hak dan kewajibannya sesuai dengan kedudukannya maka dia menjalankan suatu peranan.Pembedaan antara kedudukan dan peranan adalah untuk kepentingan ilmu pengetahuan.Pentingnya peranan adalah karena peranan mengatur perilaku seseorang. Hubungan-hubungan sosial yang ada dalam masyarakat merupakan hubungan antara peranan-peranan individu dalam masyarakat.Peranan diatur oleh normanorma yang berlaku.

Kedua, menurut Tilaar (1974) dalam kumpulan tulisan pemuda dan perubahan sosial, pemuda identik dengan pemberontak; berani tetapi pendek akal; dinamik tetapi sering kali hantam kromo. Pemuda atau kepemudaan juga merupakan suatu fase perkembangan dalam periode pertumbuhan biologis seseorang yang bersifat seketika, dan sekali waktu akan hilang dengan sendirinya sejalan dengan hukum biologis itu sendiri. Keanehan - keanehan masa pemuda akan menghilang dengan sendirinya dalam proses masa ke masa.
Ketiga, ekowisata adalah sebagian dari sustainable tourism. Sustainable tourism adalah sektor ekonomi yang lebih luas dari Ekowisata yang mencakup sektorsektor pendukung kegiatan wisata yang meliputi wisata bahari, wisata pedesaan, wisata alam, wisata budaya, atau perjalanan bisnis.Ekowisata berpijak pada tiga kaki sekaligus, yakni wisata pedesaan, wisata alam, dan wisata budaya. (Nugroho: 2011).

Marta Honey dalam Hakim (2004) memberikan kriteria-kriteria sebuah aktivitas ekowisata. Dalam aktivitasnya, ekowisata harus menjawab dan menunjukkan parameter sebagai berikut: perjalanan ke kawasan alamiah, dampak yang ditimbulkan terhadap lingkungan rendah, membangun kepedulian terhadap lingkungan, memberikan dampak keuntungan ekonomi secara langsung bagi konservasi, memberikan dampak keuangan dan pemberdayaan masyarakat lokal, adanya penghargaan terhadap budaya setempat, mendukung hak asasi manusia dan gerakan demokrasi.

Keempat, teori ketahanan masyarakat desa. Menurut Ihsan (2015) dalam buku Ketahanan Masyarakat Desa disebutkan bahwa pembangunan ketahanan masyarakat desa bertujuan untuk menjaga keberlangsungan hidup atau kemakmuran warga masyarakat desa. Dalam hal ini, yang dimaksud keberlangsungan hidup adalah kemampuan melakukan berbagai aktivitas oleh warga masyarakat desa, baik secara individu maupun kelompok untuk memenuhi kebutuhan materiil maupun immateriil secara terus menerus. Pencapaian tujuan tersebut dapat dilakukan melalui upaya pembangunan atau transformasi kelemahan menjadi kekuatan dan segala potensi untuk mendorong perubahan secara berkelanjutan. 
Sri Haryati, Armaidy Armawi, dan Muhammad Supraja -- Peran Pemuda Dalam Mengelola Kawasan Ekowisata Dan Implikasinya Terhadap Ketahanan Masyarakat Desa (Studi Tentang Pemuda Pengelola Desa Wisata Kandri, Kecamatan Gunungpati, Kota Semarang, Provinsi Jawa Tengah)

Indikator-indikator ketahanan masyarakat desa yang menjadi acuan dalam menganalis rumusan masalah yang kedua juga mengacu pada Ihsan (2015) yaitu penguatan modal sosial dan ketaatan hukum dalam diri warga, kemampuan memilih nilainilai sosial budaya dan kelembagaan sosial, kemampuan memperbaharui, memelihara, dan mengembangkan kawasan ekowisata, dan kemandirian dalam diri warga.

Kajian mengenai peran pemuda dalam mengelola kawasan ekowisata dan implikasinya terhadap ketahanan masyarakat desa dilakukan menggunakan analisis deskriptif. Peneliti melakukan analisis data kualitatif dengan cara berfikir induktif. Menurut Azwar (2001), berfikir induktif adalah proses logika yang berangkat dari data atau fakta-fakta hasil pengamatan menuju pada hubungan teori. Analisis data dilakukan terdiri dari tiga alur, yaitu: reduksi data, display data, dan penarikan kesimpulan.

\section{PEMBAHASAN}

\section{Gambaran Umum Desa Wisata Kandri}

Desa Wisata Kandri diresmikan pada tanggal 21 Desember 2012. Pemerintah Kota Semarang mengeluarkan SK WaliKota Semarang Nomor; 556/407/ Tanggal 21 Desember 2012 Tentang Penetapan Kelurahan Kandri sebagai Desa Wisata Kota Semarang. Surat Keputusan tersebut menyatakan bahwa Kelurahan Kandri Kecamatan Gunungpati Kota Semarang sebagaimana Diktum kesatu SK WaliKota Semarang diputuskan bahwa Kelurahan Kandri sebagai desa wisata berbasis daya tarik alam dan berbasis daya tarik seni budaya.

Penetapan tersebut didasari pada kondisi Desa Wisata Kandri yang telah mempunyai atraksi alam, buatan dan budaya yang cukup menarik. Atraksi alam yang dimiliki yaitu berupa identitas hayati Bambu Krincing (bambusoideae) dan identitas Fauna Kera Jawa Ekor Panjang (Mocaca Fascicularis). Atraksi alam lainnya seperti pemandangan alam juga dimiliki oleh Desa Wisata Kandri. Pemandangan alam yang terdapat pada Desa Wisata Kandri yaitu Pemandangan Goa, Pemandangan Sawah dan Pemandangan Waduk. Atraksi buatan yang telah dibangun di Desa Wisata Kandri yaitu pemandangan Waduk Jatibarang sebagai salah satu tempat daya tarik wisata. Atraksi budaya juga terdapat di Desa Wisata Kandri. Masyarakat Kelurahan Kandri sering melakukan atraksi budaya Nyadran Desa, Sesaji Rewandra dan bermain lesung yang dilakukan pada event tahunan.

Secara geografis kawasan ekowisata Desa Wisata Kandri Kelurahan Kandri terletak pada 710 Lintang Selatan (LS) dan 11035 Bujur Timur (BT) dengan luas wilayah darat 245,490 Ha (BPS Kota Semarang, 2013). Kawasan ini terletak di Kelurahan Kandri, Kecamatan Gunungpati, Kota Semarang, Provinsi Jawa Tengah. Wilayah ini memilik ketinggian 348 meter di atas permukaan air laut. Batas - batas wilayah administratif Kelurahan Kandri, Kecamatan Gunungpati, Kota Semarang, Provinsi Jawa Tengah yaitu (1). Sebelah barat berbatasan dengan Kelurahan Sadeng; (2). Sebelah selatan berbatasan dengan Kelurahan Cepoko; (3). Sebelah barat berbatasan dengan Kelurahan Jatirejo; (4). Sebelah timur berbatasan dengan Kelurahan Nongkosawit dan Pongangan.

Secara administratif Kelurahan Kandri terbagi menjadi 4 dusun. Masing-masing dusun tersebut yaitu Dusun Kandri berada di RW 1, Dusun Siwarak berada di RW 2, Dusun 
Talun Kacang berada di RW 3, dan Perumahan Kandri Pesona Asri berada di RW 4. Wilayah yang dijadikan kawasan ekowisata yaitu berada di Dusun Kandri, Siwarak, dan Talun Kacang. Secara jelas letak masing-masing dusun digambarkan dalam bentuk gambar 1 .

Gambar 1

Peta Wilayah Kelurahan Kandri

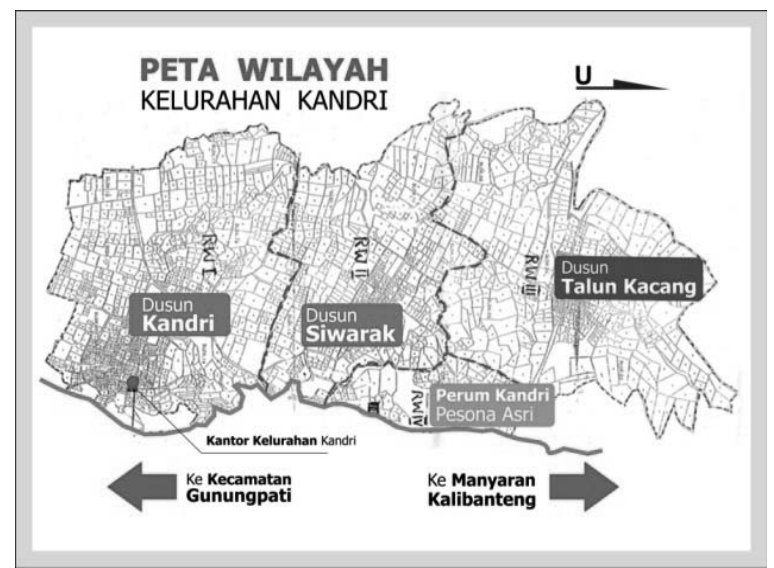

Sumber : Pengelola Kawasan Ekowisata Kandri

\section{Aksesbilitas}

Aksesbilitas mencakup keseluruhan infrastruktur transportasi yang menghubungkan wisatawan dari, ke dan selama di daerah tujuan wisata (Damanik dan Webber, 2006) mulai dari darat, laut, sampai udara. Kawasan ekowisata Desa Wisata Kandri memiliki tingkat aksesbilitas cukup baik. Hal ini ditunjang dengan kondisi jalan menuju Desa Wisata Kandri yang sudah beraspal. Kondisi sepanjang jalan raya Kecamatan Gunungpati yang dilewati untuk menuju kawasan Desa Wisata Kandri hanya saja sempit. Jalan raya hanya muat digunakan oleh mobil yang berpapasan. Bus dan kendaraan lainnya yang melebihi mobil tidak dapat berpapasan di jalan tersebut.

Kondisi jalan di dalam kawasan kelurahan ada beberapa yang belum di aspal dan masih berbatu-batuan. Kondisi tersebut terdapat di beberapa gang kecil di sekitar perumahan warga. Secara umum, konsidi jalan raya yang dilalui wisatawan untuk menuju Kelurahan Kandri sudah beraspal. Wisatawan dapat mudah melewati jalan baik pada saat musim hujan maupun kemarau.

Berdasarkan hasil observasi yang telah dilakukan, kondisi aksesbilitas untuk daerah yang dijadikan kawasan ekowisata Desa Wisata Kandri berada di daerah dataran tinggi Kota Semarang. Lokasi kawasan tersebut berada di sebuah Kelurahan Kandri yang berdekatan dengan Kabupaten Semarang. Lokasi yang dijadikan kawasan ekowisata dapat diakses melalui jalur manapun. Akses masuk dari jalan raya bermacam-macam sesuai dengan lokasi wisata yang diinginkan. Akses jalur jalan raya selamat datang Desa Wisata Kandri menuju wisata edukasi dan kuliner membutuhkan waktu kurang lebih 7 menit dengan menggunakan kendaraan motor. Akses masuk menuju Waduk Jatibarang dari jalan raya selamat datang Waduk Jatibarang membutuhkan waktu kurang lebih 4 menit menggunakan kendaraan bermotor. Sedangkan menuju Goa Kreo dari jalan raya gang masuk Goa Kreo membutuhkan waktu 10 menit dengan menggunakan kendaraan motor.

Letak kawasan ekowisata Desa Wisata Kandri yang cukup strategis serta ditunjang dengan akses yang relatif cukup baik memberikan peluang pengembangan yang sangat besar. Akses menuju kawasan tersebut mudah dijangkau, baik melalui jalur darat, laut, dan udara.

Pertama, jalur darat. Kawasan Ekowisata Desa Wisata Kandri dapat ditempuh melalui jalur darat menggunakan kendaraan umum angkutan maupun pribadi. Kawasan dapat 
Sri Haryati, Armaidy Armawi, dan Muhammad Supraja -- Peran Pemuda Dalam Mengelola Kawasan Ekowisata Dan Implikasinya Terhadap Ketahanan Masyarakat Desa (Studi Tentang Pemuda Pengelola Desa Wisata Kandri, Kecamatan Gunungpati, Kota Semarang, Provinsi Jawa Tengah)

dijangkau menggunakan kendaraan roda empat dan roda dua, bahkan kendaraan besar seperti bus, angkutan, dan truk dapat mengakses jalan menuju kawasan ini. Kawasan tersebut tidak menjadi jalur utama atau pantura yang menghubungkan berbagai antar kota, sehingga jalan tidak padat dan jarang dilalui kendaraan besar.

Berikut merupakan jalur darat menuju Kawasan Desa Wisata Kandri. (1). Dari Kawasan Pusat Kota Pemerintah Kota Semarang. Berdasarkan hasil observasi, wisatawan yang datang dari Kota Semarang dapat sampai di lokasi ini dengan waktu tempuh sekitar 35 menit jika menggunakan motor dengan kecepatan sedang yakni 60$70 \mathrm{~km} / \mathrm{jam}$. Wisatawan yang menggunakan mobil jarak tempuh kurang lebih hampir sama karena kondisi jalan tidak mengalami kemacetan. Akan tetapi jika wisatawan tidak menggunakan motor atau mobil akan mengalami kesulitan. Transportasi dari pusat kota menuju lokasi tidak melayani jurusan sampai ke sana. Transportasi yang ada hanyalah angkutan dengan cara berpindahpindah. Wisatawan dapat ikut angkutan dari pusat kota turun ke Kalibanteng, kemudian naik angkutan jurusan Manyaran, baru kemudian naik angkutan jurusan Gunungpati Kalipancur kemudian turun di jalan masuk lokasi. (2). Dari Yogyakarta. Berdasarkan hasil observasi, wisatawan yang datang dari Yogyakarta dan sekitarnya dapat sampai ke lokasi ini dengan waktu tempuh sekitar 3,5 jam. Wisatawan melewati Kota Magelang, kemudian Ambarawa, dan sebelum memasuki Kota Semarang belok ke arah Alun-alun Ungaran Kabupaten Semarang menuju arah Kecamatan Gunungpati. Rute dari Yogyakarta dan sekitarnya lebih dekat melewati Kecamatan
Ungaran Kabupaten Semarang dari pada melewati jalur Kota Semarang.

Kedua, jalur laut. Pelabuhan yang memiliki jarak terdekat dengan kawasan Ekowisata Desa Wisata Kandri adalah pelabuhan Tanjung Mas Kota Semarang. Apabila wisatawan akan berkunjung melalui jalur laut, maka harus berhenti di pelabuhan Tanjung Mas. Wisatawan kemudian dapat melanjutkan perjalanan melalui jalur darat dengan jarak tempuh sekitar 50 menit.

Ketiga, jalur udara. Bandar udara terdekat dengan posisi kawasan ekowisata Desa Wisata Kandri adalah Bandara Ahmad Yani. Apabila wisatawan akan berkunjung ke kawasan tersebut melalui jalur udara maka harus melalui Bandara Ahmad Yani yang terletak di Kota Semarang. Wisatawan kemudian dapat melakukan perjalanan darat selama sekitar 25 menit.

Sarana transportasi yang digunakan menuju kawasan ekowisata Desa Wisata Kandri adalah sepeda,motor, mobil, dan bus. Jarak lokasi kawasan atraksi alam, wisata edukasi, dan kuliner cukup berjauhan, sehingga biasanya masyarakat menggunakan motor untuk beraktivitas. Hampir semua rumah mempunyai kendaraan motor sebagai sarana transportasi untuk memudahkan aktivitas sehari-hari seperti ke sawah, berangkat kerja, ke pasar dan lain sebagainya.

\section{Amenitas}

Amenitas adalah infrastruktur yang sebenarnya tidak langsung terkait dengan pariwisata tetapi sering menjadi bagian dari kebutuhan wisatawan (Damanik dan Webber, 2006). Infrastruktur di kawasan ekowisata Desa Wisata Kandri ini dapat membantu kenyamanan para wisatawan. 
Infrastruktur yang mendukung antara lain beberapa jalan yang sudah bagus, air yang jernih dan berlimpah, adanya listrik dan manajemen sampah yang sudah baik.

Infrastruktur berupa fisik yang terdapat pada Desa Wisata Kandri yaitu Pusat Informasi, Pendopo Omah Pinter Petani, Tempat Parkir, Kamar Mandi, Homestay, Masjid, dan Balai Desa. Adanya infrastruktur yang ada telah membantu para pemuda dalam melakukan proses kegiatan wisata yang disediakan bagi para pengunjung. Infrastruktur tersebut secara tidak langsung telah memberikan kontribusi yang cukup besar untuk memfasilitasi kebutuhan wisatawan.

\section{Peran Pemuda Dalam Mengelola Kawasan Ekowisata Desa Wisata Kandri}

\section{Aktor Pemuda Pengelola Kawasan Ekowisata}

Pengelola kawasan ekowisata di Desa Wisata Kandri awalnya dikelola langsung oleh Pokdarwis Pandanaran. Selama satu tahun, Pokdarwis Pandanaran tidak mampu mendatangkan wisatawan. Pokdarwis Pandanaran dalam menangani hal ini kemudian membentuk beberapa kelompok kerja (pokja). Pokja yang telah dibentuk yaitu Pokja Mekar Sari yang terdiri dari mayoritas ibu-ibu rumah tangga, dan Pokja Pandu Wisata Jaya dan Pokja Pandu Jaya yang mayoritas berasal dari kalangan pemuda.

Jumlah keseluruhan pemuda di Kelurahan Kandri yang ikut serta dalam pokja yang diperuntukkan bagi pemuda hanya 16 pemuda dari 900 an pemuda. Menurut hasil wawancara, sosialisasi diawal yang dilakukan oleh pokdarwis dalam perekrutan pemuda kurang maksimal. Perekrutan dilakukan tidak secara serentak kepada seluruh pemuda, akan tetapi dilakukan secara acak yang mampu terjangkau. Latar belakang Pokdarwis Pandanaran dalam memilih perekrutan yaitu dilatarbelakangi oleh batasan wilayah tanggungjawab Pokdarwis Pandanaran. Adanya batasan tersebut menyebabkan Pokdarwis Pandanaran hanya merekrut sebagian pemuda yang menjadi cakupan wilayahnya yaitu pemuda di RW I dan II. RW III memiliki pokdarwis tersendiri yang sekarang kurang aktif yaitu Pokdarwis Sukamakmur.

Kondisi tersebut juga didukung dengan keadaan pemuda di Kelurahan Kandri yaitu mayoritas pemuda sudah sibuk bekerja, beberapa pemuda yang kuliah di luar Kota Semarang, dan beberapa pemuda yang senang dengan kehidupannya sendiri walaupun sebagai pekerja serabutan. Keempat kondisi tersebut telah menyebabkan hanya 16 pemuda yang aktif dalam mengelola kawasan ekowisata. Masing - masing pemuda tersebut akan dijelaskan sebagai berikut:

Pertama, Kelompok Kerja Pandu Wisata Jaya. Kelompok Kerja Pandu Wisata Jaya merupakan perkumpulan pemuda yang menangani kegiatan Nyawah, Outbound dan Goa Kreo. Pemuda yang berkumpul dalam pokja ini hanya berjumlah 6 orang. Segala persiapan kebutuhan kegiatan dilakukan oleh seluruh anggota. Setiap anggota juga terkadang mendapatkan tugas yang berbeda maupun double job. Kondisi tersebut disesuaikan dengan jumlah wisatawan yang datang dan anggota yang dapat hadir dalam kegiatan. Penentuan tugas dilakukan setiap ada calon wisatawan yang telah memesan kegiatan. Para pengurus pokja ini melakukan koordinasi setiap ada calon wisatawan yang akan berkunjung. 
Sri Haryati, Armaidy Armawi, dan Muhammad Supraja -- Peran Pemuda Dalam Mengelola Kawasan Ekowisata Dan Implikasinya Terhadap Ketahanan Masyarakat Desa (Studi Tentang Pemuda Pengelola Desa Wisata Kandri, Kecamatan Gunungpati, Kota Semarang, Provinsi Jawa Tengah)

Enam pemuda tersebut mempunyai aktivitas yang berbeda-beda dalam kehidupan seharihari. Jenjang pendidikan yang dimiliki beranekaragam. Perbedaan tersebut tidak menimbulkan kecemburuan sosial di antara satu dengan lainnya. Gotong royong dan cinta tanah kelahiran menjadi menjadi satu tujuan yang sama.

Kedua, Kelompok Kerja Pandu Jaya. Kelompok kerja Pandu Jaya merupakan perkumpulan pemuda yang menangani bidang Wisata Sungai. Wisata tersebut dikenal dengan wisata River Tubing. Pemuda yang aktif di kelompok ini sebagian juga aktif di Pokja Pandu Wisata Jaya. Jumlah keseluruhan pemuda pada pokja ini yaitu 13 pemuda, 3 pemuda juga aktif dalam Pokja Pandu Wisata Jaya. Tiga pemuda mempunyai peran ganda dalam mengelola kawasan ekowisata.

\section{Faktor Pendorong}

Motivasi dalam diri seseorang merupakan kekuatan besar untuk bersikap, bertindak dan berkata. Seperti yang diungkapkan oleh Nuriana (2014) bahwa motivasi dapat diartikan sebagai sebuah dorongan dari dalam atau hasrat seseorang untuk menggerakkan atau melakukan kegiatan dan tindakan mencapai kepuasan atas sesuatu yang diinginkan. Menurut data lapangan yang telah di dapat, terdapat 2 faktor yang mendorong pemuda untuk bergerak dalam mengelola kawasan ekowisata. Kedua faktor tersebut yaitu faktor intriksik dan ektrinsik. Faktor intrinsik yaitu faktor yang berasal dari dalam diri pemuda. Faktor ekstrinsik yaitu faktor yang berasal dari luar diri pemuda atau faktor yang muncul karena keadaan lingkungan sekitar.

Faktor intrinsik yang menjadi pendorong pemuda dalam ikut serta mengelola kawasan ekowisata yaitu (1). Adanya semangat dan komitmen pemuda membangun desa. Semangat pemuda telah menumbuhkan sebuah komitmen dan percaya diri. Rasa lelah dan kesibukan yang dimiliki pemuda tidak menjadi penghalang untuk selalu berperan dalam mengelola kawasan ekowisata. Kekuatan tersebut telah menjadi alat untuk mengantarkan pemuda dalam menjalankan tugasnya masing-masing. (2). Rasa peduli terhadap Desa Wisata Kandri. Rasa peduli yang dimiliki oleh pemuda terhadap adanya Desa Wisata Kandri memunculkan kontribusi untuk ikut berperan di dalamnya. Kepedulian tersebut dilatarbelakangi oleh tidak adanya kegiatan wisatawan selama satu tahun setelah diresmikan menjadi desa wisata. Kondisi tersebut membuat beberapa pemuda berfikir untuk mengadakan kegiatan dan mendatangkan wisatawan. (3). Harapan menjadikan Desa Wisata Kandri menjadi lebih baik. Pemuda mempunyai harapan yang besar terhadap adanya Desa Wisata Kandri. Harapan-harapan yang ingin diwujudkan pemuda yaitu mengembalikan kesejahteraan masyarakat dan meningkatkan kemandirian dalam diri pemuda. Kedua harapan tersebut menjadikan pemuda bersemangat untuk selalu mengaktifkan kegiatan di Desa Wisata Kandri. Kekurangan-kekurangan yang dimiliki dapat tertutupi dengan adanya harapan - harapan yang ingin diwujudkan.

Faktor ekstrinsik juga menjadi pelengkap adanya pendorong pemuda dalam aktif mengelola kawasan ekowisata. Faktor faktor ekstrinsik tersebut yaitu (1). Hilangnya sebagian lahan pertanian milik warga. Kejadian hilangnya lahan sebagian milik warga telah memberikan pengaruh terhadap perekonomian masyarakat Kelurahan Kandri. 
Pengaruh tersebut mendorong pemuda untuk meningkatkan perekonomian masyarakat dengan mengaktifkan kegiatan di Desa Wisata Kandri. (2). Adanya destinasi wisata lain. Destinasi wisata Borobudur dan desa wisata di sekitarnya telah menjadi sebuah referensi dan stimulan untuk mengaktifkan Desa Wisata Kandri. Pemuda melihat kesuksesan destinasi yang terdapat di Borobudur dan sekitarnya. Hal tersebut telah menimbulkan keyakinan pada diri pemuda bahwa setiap daerah dapat mengembangkan wisata di daerahnya masingmasing dengan potensi yang dimiliki.

Faktor - faktor tersebut merupakan alat penggerak para pemuda untuk berkeinginan dalam membantu mengelola kawasan ekowisata. Kedua faktor tersebut yang menjadi alasan 16 pemuda bergabung dalam Pokja Pandu Wisata Jaya dan Pandu Jaya. Faktor yang dimiliki menjadi salah kekuatan para pemuda dalam berperan dan melawan kekurangan-kekurangan pengetahuan serta pengalaman tentang ekowisata.

\section{Bentuk Peran Pemuda}

Bentuk peran pemuda dalam mengelola kawasan ekowisata lebih banyak terlihat pada salah satu indikator ekowisata menurut Hakim (2004) yaitu perjalanan ke kawasan alamiah. Perjalanan ke kawasan alamiah tersebut berupa Wisata Nyawah, Wisata Outbound, Wisata Goa Kreo, dan Wisata River Tubing. Menurut analisis peneliti, para pemuda saat ini lebih berperan di wisata tersebut karena kondisi alam dan kebiasaan masyarakat Kelurahan Kandri yang mendukung. Kondisi alam berupa sawah dan sungai menjadi tempat aktivitas yang sering dilakukan oleh masyarakat Kelurahan Kandri untuk bercocok tanam dan bermain air di Sungai. Bentuk - bentuk wisata yang telah dikonsep dan dilakukan para pemuda akan dijelaskan di bawah ini.

Pertama, Wisata Nyawah. Kegitatan yang terkait dengan wisata ini adalah sebagai berikut.

(1). Memperkenalkan tanaman sawah kepada wisatawan. Kegiatan Nyawah yang telah dikonsep oleh pemuda diawali dengan memperkenalkan tanaman sawah kepada wisatawan. Aktivitas ini merupakan langkah awal untuk mengajak para wisatawan mengenal lebih dekat dengan pertanian. Pemuda menjelaskan kepada wisatawan jenis, fungsi, dan bagaimana petani menanam tanaman tersebut. Para wisatawan juga diperkenankan mencabut tanaman yang sudah disediakan sebagai praktek bertani.

(2). Menjelaskan manfaat tanaman jambu. Wisatawan setelah diperkenalkan tanaman sawah oleh pemandu kemudian menuju kebun jambu. Kebun jambu biji terletak di sekitar lahan pertanian. Pada wisata jambu ini, pemandu menjelaskan tentang manfaat pohon jambu. Para wisatawan dianjurkan untuk memegang ranting, daun, dan buah untuk mengenali lebih dekat. Wisatawan juga dapat melihat-lihat kawasan kebun jambu. Jambu yang sudah masak dapat dipetik oleh wisatawan dan dibawa pulang.

(3). Mengajarkan menanam padi. Wisata menanam padi ini merupakan salah satu Wisata Nyawah yang menyenangkan. Realita ini terlihat ketika para wisatawan turun ke sawah dan menanam padi sesuai yang diarahkan oleh para pemandu. Langkahlangkah yang dilakukan pemuda dalam kegiatan ini yaitu pemandu memperkenalkan terlebih dahulu tanaman yang akan ditanam dan menjelaskan tentang cara menanamnya. Tanaman yang akan ditanam yaitu berupa 
Sri Haryati, Armaidy Armawi, dan Muhammad Supraja -- Peran Pemuda Dalam Mengelola Kawasan Ekowisata Dan Implikasinya Terhadap Ketahanan Masyarakat Desa (Studi Tentang Pemuda Pengelola Desa Wisata Kandri, Kecamatan Gunungpati, Kota Semarang, Provinsi Jawa Tengah)

padi. Metode penanaman padi yang diajarkan yaitu menanam dengan berjalan mundur. Masing - masing wisatawan diberikan padi untuk ditanam sesuai yang diarahkan oleh pemandu. Orang Jawa menyebut kegiatan ini dengan sebutan matun.

(4). Mengajarkan menanam singkong. Kegiatan praktek yang harus dilakukan oleh wisatawan lagi yaitu menanam singkong. Menanam singkong merupakan kegiatan yang dilakukan pada paket wisata edukasi berupa Wisata Nyawah dan juga Wisata Kuliner. Menanam singkong pada paket Wisata Nyawah merupakan salah satu kegiatan yang dilakukan sebagai pembelajaran penanaman bahan baku makanan khas Kelurahan Kandri yaitu ketela pohong. Kegiatan mengajarkan menanam singkong ini dimulai dengan pengenalan bibit pohon singkong. Pemandu memperlihatkan bibit yang akan ditanam. Pemandu menjelaskan terlebih dahulu manfaat dan kegunaan pohong singkong. Mulai dari batang, daun, dan hasilnya. Pemandu kemudian mempraktekkan cara menancapkan bibit singkong pada tanah yang sudah disediakan. Wisatawan kemudian mempraktekkan secara bersama-sama dengan diawasi dan diarahkan oleh pemandu.

(5). Pembelajaran menangkap ikan. Menangkap ikan menjadi salah satu kegiatan yang berbeda dari paket Wisata Nyawah. Kegiatan sebelumnya yang dilakukan wisatawan hanya belajar tentang tanaman. Pada kegiatan ini wisatawan diajak untuk lebih dekat dengan air dan ikan. Para pemuda menyiapkan lahan yang digenangi air untuk dapat dimasukan ikan ke dalamnya. Ikan yang biasa digunakan yaitu ikan lele maupun nila. Ikan yang digunakan merupakan ikan dari kolam masyarakat yang siap untuk dipanen.
Kedua, Wisata Outbound. Outbound merupakan salah satu permainan yang dikonsep oleh para pemuda untuk membuat wisatawan senang. Jenis Outbound yang diadakan disesuaikan dengan jenis wisatawan yang datang. Outbound untuk wisatawan anakanak tidak sama dengan Outbound bagi para wisatawan golongan tua. Konsep ini bertujuan agar mampu menarik hati para wisatawan.

Pada Outbound di kalangan anak-anak, pemuda melatih kecermatan, ketangkasan, dan juga kerja sama pada. Pemuda juga melatih anak-anak untuk bersikap berani, percaya diri, memimpin, dan jujur. Saat musin durian, pemuda menyiapkan durian sebagai hadiah bagi kelompok Outbound yang menang. Hadiah ini merupakan salah satu penghargaan yang diberikan kepada wisatawan sekaligus memperkenalkan salah satu buah hasil dari bumi Desa Wisata Kandri.

Outbound yang dikonsep bagi kalangan tua bertujuan untuk mengajak para wisatawan berolah raga dengan menggunakan sepeda. Para pemuda juga mengajak wisatawan untuk menikmati nuansa di pedesaan dengan mengayuh sepeda ontel zaman dahulu. Para wisatawan kemudian diajak berkreasi membuat orangorangan sawah dari kertas koran.

Ketiga, Wisata Goa Kreo. Wisata Goa Kreo merupakan wisata yang dimiliki Kelurahan Kandri sebelum diresmikan menjadi Desa Wisata Kandri. Goa Kreo dikelola langsung oleh pemerintah Kota Semarang. Retribusi administrasi wisatawan maupun anggaran pengelolaannya dikelola oleh pemerintah Kota Semarang. Masyarakat hanya ikut andil dalam menyediakan pusat makanan di depan Wisata Goa Kreo.

Pemuda dalam mempersiapkan paket wisata di Desa Wisata Kandri juga 
mengikutsertakan Goa kreo masuk dalam salah satu paket wisata. Wisatawan tidak akan mengeluarkan anggaran untuk masuk dalam kawasan Goa kreo. Anggaran paket yang dipilih sudah termasuk tiket masuk Goa Kreo. Wisatawan hanya mengikuti kegiatan yang sudah dikonsep oleh para pemuda.

Wisata Goa Kreo yang dikelola oleh para pemuda berbeda dengan wisata yang dilakukan secara pribadi. Wisatawan akan lebih mendapatkan banyak pengetahuan tentang Goa Kreo pada paket ini. Para pemuda menjadi guide bagi wisatawan. Guide menjelaskan segala tempat di kawasan Goa Kreo, mulai dari sejarah, nama benda dan lainnya. Wisatawan secara tidak langsung dalam kegiatan ini mendapatkan pendidikan tentang Goa Kreo. Kebanyakan wisatawan yang mengambil paket ini berdasarkan informasi adalah para siswa sekolah. Paket ini dirasa sangat membantu para siswa untuk mendapatkan pengetahuan dan pengalaman di luar sekolah.

Keempat, Wisata River Tubing. Wisata River Tubing merupakan satu-satunya paket wisata yang menggunakan atraksi alam berupa sungai. Kegiatan ini merupakan kegiatan yang sering diminati oleh para wisatawan muda. Aktivitas wisata ini yaitu menelurusi sungai dengan menggunakan alat pembantu seperti ban, helm, dan pelampung. Wisata ini membutuhkan tenaga yang cukup banyak karena sesuai dengan tingginya resiko keamanan yang dihadapi. Penanggungjawab dan pelaksana dari kegiatan ini yaitu Pokja Pandu Jaya.

\section{Kendala-Kendala dan Upaya Yang Dilakukan}

\section{Kendala - Kendala}

Pelaksanaan peran pemuda dalam mengelola kawasan ekowisata di Desa
Wisata Kandri tidak hanya memiliki faktorfaktor pendorong tetapi juga terdapat kendala yang menghambat dalam proses mengelola kawasan tersebut. Kendala tersebut dapat mengakibatkan hasil yang kurang maksimal dalam pelaksanaannya. Adapun faktor-faktor yang menjadi kendala peran pemuda dalam mengelola kawasan ekowisata di Desa Wisata Kandri adalah sebagai berikut.

Pertama, kurangnya sarana dan prasarana yang memadai. Berdasarkan data lapangan yang telah didapat, peneliti melihat bahwa sarana dan prasarana yang dimiliki oleh pemuda dalam mengelola kawasan ekowisata belum memadai. Sarana dan prasarana yang belum terdapat di Desa Wisata Kandri yaitu kesekretariatan, papan penunjuk arah di dalam kawasan, dan papan selamat datang Desa Wisata Kandri yang kurang memadai. Peralatan kecil yang belum dimiliki yaitu alat komunikasi HT, kamera milik Desa Wisata Kandri dan alat pengeras suara yang jernih untuk di lapangan. Peralatan dalam kegiatan River Tubing yang dimiliki masih sedikit.

Salah satu faktor penyebab kurangnya sarana dan prasarana yang memadai yaitu dana. Dana yang sedikit tidak mampu mencukupi kebutuhan sarana prasarana yang mendukung. Para pemuda dapat melengkapi sarana dan prasarana secara perlahan-lahan sesuai dengan dana yang ada. Manajemen keuangan dalam pengelolaan menjadi salah satu solusi untuk membantu mengatasi permasalahan tersebut.

Kedua, kurangnya pengetahuan pemuda tentang ekowisata. Sumber daya manusia memiliki peranan penting dalam mengoperasikan jasa ekowisata. Melalui keahlian, ketrampilan dan kreativitas dapat mengembangkan kawasan ekowisata. Kebijakan manajemen yang tepat, pengenalan 
Sri Haryati, Armaidy Armawi, dan Muhammad Supraja -- Peran Pemuda Dalam Mengelola Kawasan Ekowisata Dan Implikasinya Terhadap Ketahanan Masyarakat Desa (Studi Tentang Pemuda Pengelola Desa Wisata Kandri, Kecamatan Gunungpati, Kota Semarang, Provinsi Jawa Tengah)

dan pemanfaatan SDM dan organisasi, disertai kebijakan intensif, akan menghasilkan tanggungjawab secara penuh dalam pengelolaan jasa ekowisata berkelanjutan (Nugroho: 2011). Sumber daya manusia yang memadai tentang ekowisata sangat berpengaruh dalam mengelola kawasan.

Para pemuda yang ikut andil dalam mengelola kawasan ekowisata pada dasarnya tidak memiliki pengetahuan tentang ekowisata. Semua kegiatan yang dilakukan merupakan otodidak yang keluar ketika diberi tanggungjawab dalam mengelola kawasan.

Ketiga, ketidakharmonisan hubungan pokja dengan pemuda RW III. Interaksi sosial dalam sebuah masyarakat sangat diperlukan untuk menjalin kerjasama serta gotong royong. Interaksi sosial merupakan hubunganhubungan sosial yang dinamis menyangkut hubungan antara orang-orang perorangan. Antara kelompok - kelompok manusia, maupun antara orang perorangan dengan kelompok manusia (Soekanto, 1992).

Pengaruh ketidakikutsertaan RW III diawal dalam mengelola kawasan ekowisata telah menimbulkan perbedaan persepsi bagi pengelola. Kondisi ini didukung dengan tindakan RW III dengan membuat kegiatan River Tubing yang menjadi konsep pengelola. Kecerobohan yang dilakukan oleh RW III justru memberikan kerugian yang besar terhadap pengelola dengan sempat divakumkannya kegiatan tersebut.

Pengelola merasa sangat kecewa terhadap tindakan RW III. Kekecewaan yang dialami yaitu difakumkannya River Tubing hampir selama satu tahun, mencemarkan nama baik Desa Wisata Kandri, dan juga mengurangi pendapatan pengelolaa. Keadaan ini menimbulkan perpecahan antara kedua belah pihak. Ketidakharmonisan di antara keduanya menjadi salah satu penghambat pemuda dalam mengelola kawasan ekowisata.

Keempat, Pemuda yang ikut andil dalam pengelolaan masih sedikit. Jumlah anggota pengelola merupakan bagian terpenting dalam mengelola sebuah wisata apalagi wisata sosial. Keadaan ini menjadi kekhawatiran bagi para pemuda. Sebagian besar anggota yang masuk dalam Pokja Pandu Wisata Jaya juga aktif dalam Pokja Pandu Jaya. Rasa khawatir tersebut muncul dengan melihat keadaan para anggota. Setiap anggota mempunyai kesibukan masing-masing. Kondisi kesehatan masing-masing anggota juga berbeda-beda. Kesibukan dan kondisi kesehatan yang kurang baik menjadi kekhawatiran bersama ketika datang secara bersamaan.

\section{Upaya Yang Dilakukan}

Berdasarkan data lapangan serta wawancara yang dilakukan oleh peneliti, ditemukan bahwa upaya yang dilakukan oleh para pemuda dalam mengelola kawasan ekowisata sebagai berikut.

Pertama, Memanfaatkan sarana dan prasarana yang ada. Hal ini menjadi salah satu upaya yang telah dilakukan oleh para pemuda. Strategi ini dilakukan dengan tujuan untuk memenuhi kebutuhan dalam melaksanakan kegiatan wisata. Sarana yang paling mendukung yaitu adanya Omah Pinter Petani. Sarana ini merupakan pendukung berjalannya kegiatan walaupun masih kurang memadai. Kebutuhan seperti parkir, tempat berkumpul wisatawan, tempat istirahat, dan toilet dapat menggunakan Omah Pinter Petani. Para pemuda juga memanfaatkan alat komunikasi handphone milik pribadi masingmasing sebagai komunikasi antar pemuda maupun wisatawan. Perlengkapan pengeras 
suara seperti megaphone didapatkan dari sekretariatan Pokdarwis Pandanaran.

Kedua, keberanian berinovasi. Berbagai kendala yang dihadapi oleh para pemuda dalam mengelola kawasan ekowisata tersebut tidak menjadi sebuah hambatan. Para pemuda selalu berupaya untuk menemukan berbagai cara dalam membuat kegiatan untuk wisatawan. Berdasarkan hasil wawancara yang telah dilakukan bahwa kunci terpenting yang harus dimiliki para pemuda adalah keberanian dalam berinovasi. Keberanian dalam berinovasi ini telah dibuktikan dengan adanya konsep-konsep wisata yang telah dibuat tanpa mempunyai pengetahuan yang memadai. Keberanian berinovasi ini ditunjukkan dengan munculnya konsep Wisata River Tubing dan Outbound Sepeda Ontel. Wisata River Tubing terinspirasi dengan adanya kebiasaan yang dilakukan pemuda Kelurahan Kandri yaitu bermain di sungai. Kebiasaan tersebut kemudian dikemas dengan konsep yang aman dan menyenangkan yaitu berupa konsep Wisata River Tubing.

Ketiga, fokus di atraksi wisata lain.

Strategi merupakan keseluruhan operasi intelektual dan fisik yang diniscayakan untuk menanggapi, menyiapkan, dan mengendalikan setiap kegiatan kolektif di tengah-tengah konflik (Joesoef, 2014). Strategi sangat penting dilakukan untuk mengatasi permasalahan yang ada. Berdasarkan data lapangan, para pemuda juga telah menggunakan strategi dalam mengatasi permasalahan difakumkannya kegiatan River Tubing. Sebagai pengganti kegiatan tersebut, para pemuda memfokuskan kegiatan di wisata lain seperti Nyawah, Goa Kreo, dan Outbound.

\section{Terkelolanya Kawasan Ekowisata}

Peran pemuda dalam mengelola kawasan ekowisata baru aktif pada salah satu indikator ekowisata berupa perjalanan ke kawasan alamiah. Kegiatan tersebut terdiri dari wisata alam berupa Wisata Nyawah, Wisata Outbond, Wisata Goa Kreo, dan Wisata River Tubing. Keberhasilan pemuda pengelola dalam indikator ini dipengaruhi oleh budaya masyarakat Kelurahan Kandri yaitu bertani, berkebun dan bermain di sungai. Para pemuda mendapatkan inspirasi tersebut berdasarkan kebiasaan tersebut.

Pengelolaan terhadap masyarakat secara keseluruhan terutama pemuda belum mampu dikelola dengan baik oleh para pemuda pengelola. Pemuda masih lemah dalam mengelola keseluruhan pemuda di Kelurahan Kandri. Hal tersebut dilatarbelakangi oleh proses awal perekrutan pemuda yang dilakukan oleh Pokdarwis Pandanaran dan manajemen pengelolaan yang dimiliki pemuda pengelola masih lemah, sehingga kendala yang dihadapi belum mampu terpenuhi dengan baik. Manajemen pengelolaan ekowisata menurut Richardson dan Fluker (2004) seperti kegiatan konsultasi dengan semua pemangku kepentingan belum terlaksana dengan baik. Pengidentifikasian isu, penyusunan kebijakan, pembentukan dan pendanaan dengan agen khusus belum berjalan dengan maksimal. Penyelesaian konflik belum mampu ditangani oleh pemuda pengelola karena manajemen krisis yang tidak dilakukan terlebih dahulu.

Semua tindakan yang telah dilakukan oleh pemuda pengelola dalam mengelola kawasan ekowisata juga tidak terlepas dengan adanya salah satu sisi sosok pemuda, bahwa usaha-usaha yang dilakukan pemuda adalah untuk menyaluran potensi yang bersifat fragmentaris karena potensi itu dilihat bukan dari aktivitas, akan tetapi sebagai penyalur tenaga yang berlebihan (Tilaar, 1974). 
Sri Haryati, Armaidy Armawi, dan Muhammad Supraja -- Peran Pemuda Dalam Mengelola Kawasan Ekowisata Dan Implikasinya Terhadap Ketahanan Masyarakat Desa (Studi Tentang Pemuda Pengelola Desa Wisata Kandri, Kecamatan Gunungpati, Kota Semarang, Provinsi Jawa Tengah)

Pemuda dalam mengatasi kondisi yang telah terjadi yaitu dengan cara memperbaiki segala permasalahan yang ada. Pemuda pengelola dapat memperbaiki manajemen pengelolaan. Menjalin komunikasi yang erat terhadap Pokdarwis Pandanaran juga harus dilakukan sebagai penyalur komunikasi terhadap Pokdarwis Sukomakmur dalam perekrutan pemuda di RW III.

\section{Implikasinya Ketahanan Masayarakat Desa \\ Kriteria Ketahanan Masyarakat Desa}

Peran pemuda dalam mengelola kawasan ekowisata memiliki pengaruh terhadap ketahanan masyarakat desa. Penempatan implikasi ketahanan masyarakat desa mengacu pada indikator-indikator ketahanan masyarakat desa. Berikut akan dijelaskan masing-masing gambaran indikator yang telah dihasilkan oleh peran pemuda dalam mengelola kawasan ekowisata di Desa Wisata Kandri:

Pertama, penguatan modal sosial dan ketaatan hukum dalam diri warga. Penguatan modal sosial dan ketaatan hukum dalam diri warga merupakan kriteria pertama dari ketahanan masyarakat desa. Modal sosial dan ketaatan hukum dalam diri warga merupakan bagian terpenting dalam kehidupan bermasyarakat. Adanya masyarakat yang mempunyai jiwa sosial tinggi dan taat terhadap hukum yang berlaku akan menjadikan sebuah desa yang unggul.

Kondisi masyarakat Desa Wisata Kandri telah mengalami peningkatan pada modal sosial serta ketaatan terhadap hukum. Kondisi sosial masyarakat sebelum terbentuknya Desa Wisata Kandri masih sama seperti desa-desa pada umumnya. Kerja bakti, gotong royong, serta kumpulan desa masih tetap berjalan. Perubahan modal sosial masyarakat Desa
Wisata Kandri yaitu meningkatnya komunikasi antar warga.

Ketaatan hukum dalam diri warga juga tercermin dalam keamanan produk yang dihasilkan. Pembuatan label aman pada produk makanan menjadi bukti ketaatan hukum yang dilakukan oleh masyarakat. Peningkatan ketaatan hukum ini bagus bagi perkembangan masyarakat menjadi warganegara yang baik.

Berdasarkan berbagai data yang ada, peneliti telah menemukan bahwa penguatan modal sosial dan ketaatan hukum dalam diri warga terlihat dengan adanya (1) meningkatnya komunikasi warga terhadap sesama dan orang lain, dan (2) menciptakan rasa aman terhadap produk yang dihasilkan.

Kedua, Kemampuan dalam memilih nilai-nilai sosial budaya dan kelembagaan sosial. Adanya peran pemuda juga telah memberikan pengaruh negatif terhadap pemuda lainnya khususnya pemuda di RW III. Pengaruh ini telah menimbulkan kecemburuan sosial terhadap pemuda di RW III dengan adanya Wisata River Tubing yang telah dilaksanakan. Faktor yang melatarbelakangi kecemburuan sosial tersebut yaitu kawasan yang dijadikan Wisata River tubing berada di sekitar kawasan RW III.

Pengaruh ini merupakan salah satu dampak ekowisata pada aspek sosial yaitu pengaruh negatif diferensiasi struktur sosial (WTO, 1980). Pada point pertama telah dijelaskan bahwa pengaruh negatifnya yaitu polarisasi antar penduduk karena proporsi pendapatan yang tidak seimbang antar kelompok masyarakat. Realita ini terjadi pada pemuda di Kelurahan Kandri. Proporsi pendapatan pemuda yang tidak seimbang memunculkan perbedaan bentuk pada pola fikir pemuda RW III. 
Realita yang terjadi pada pemuda juga didukung dengan adanya dampak terhadap distribusi pengaruh dan kekuasaan. Penyebaran pengaruh dan kekuasaan terhadap kawasan ekowisata berdasarkan observasi yang telah dilakukanya itu di dominasi oleh pemuda RW I dan II. Kondisi tersebut didukung dengan tidak adanya perencanaan manajemen resiko berupa pendekatan manajemen tradisional yang dilakukan oleh pemuda Kandri. Perencanaan pendekatan manajemen tradisional untuk mengantisipasi adanya krisis tidak terdapat pada kelompok pemuda Kandri. Faktorfaktor tersebut telah memunculkan dampak ekowisata, yaitu ekowisata telah mengubah struktur internal pemuda sehingga terjadi perbedaan antara mereka yang mempunyai hubungan ekowisata dan pemuda yang tidak. Keterkaitan dengan ekowisata menjadi salah satu pemisah atau pembeda dalam pemuda (Mathieson dan Wall, 1982)

Ketiga, kemampuan memperbaharui dan memelihara kawasan ekowisata. Keadaan Kelurahan Kandri sebelum menjadi sebuah esa wisata sempat mengalami penurunan terhadap kawasan alam. Masyarakat belum mampu memelihara sebagian kawasan pertanian. Masyarakat juga belum mampu memelihara kondisi alam pedesaan. Adanya perumahan yang telah dibangun memberikan gambaran bahwa masyarakat belum mampu melestarikan keadaan pedesaan tersebut.

Adanya desa wisata yang aktif telah memunculkan kesepatan bersama oleh masyarakat Kelurahan Kandri. Kesepakatan tersebut yaitu berupa dilarangnya pendirian perumahan lagi di kawasan Kelurahan Kandri. Kesepakatan tersebut dibuat berdasarkan pengalaman yang pernah terjadi yaitu kawasan RW 4 dijadikan sebuah perumahan. Kondisi sosial masyarakat pada kawasan perumahan dan biasa terlihat berbeda.

Keempat, kemandirian dalam diri warga. Kemandirian merupakan langkah awal untuk menuju masyarakat yang lebih maju. Kemandirian dalam bidang ekonomi sangat berpengaruh terhadap kesejahteraan masyarakat. Usaha dan upaya yang dilakukan sendiri tanpa mengandalkan orang lain menjadikan masyarakat lebih kuat, kreatif dan inovatif. Kriteria keempat dari ketahanan masyarakat desa ini juga ditemukan pada masyarakat Desa Wisata Kandri. Kawasan ekowisata yang telah dikelola dengan baik mempengaruhi pemikiran masyarakat untuk lebih mandiri dalam bidang ekonomi. Perubahan kemandirian ekonomi didominasi oleh kalangan ibu-ibu rumah tangga. Para ibu rumah tangga dahulu tidak mempunyai pekerjaan, akan tetapi setelah adanya desa wisata mampu menciptakan lapangan pekerjaan bagi para ibu rumah tangga. Kalangan ibu rumah tangga kebanyakan terhimpun dalam Pokja Mekar Sari. Produk yang dihasilkan juga menciptakan pasar pagi setiap hari minggu. Pasar tersebut dikenal dengan Pasar Krempyeng.

\section{Ketahanan Masyarakat Desa Yang Dihasilkan}

Segala upaya dan usaha yang telah dilakukan pasti menghasilkan pengaruh bagi lingkungan sekitar. Baik pengaruh dari segi ekonomi, sosial, budaya dan lain sebagainya. Pengaruh yang ada memberikan perubahan yang terjadi pada masyarakat maupun lingkungan sekitar. Kondisi ini juga dialami oleh masyarakat Desa Wisata Kandri.

Adanya peran pemuda dalam mengelola kawasan ekowisata di Desa Wisata Kandri 
Sri Haryati, Armaidy Armawi, dan Muhammad Supraja -- Peran Pemuda Dalam Mengelola Kawasan Ekowisata Dan Implikasinya Terhadap Ketahanan Masyarakat Desa (Studi Tentang Pemuda Pengelola Desa Wisata Kandri, Kecamatan Gunungpati, Kota Semarang, Provinsi Jawa Tengah)

belum menghasilkan pengaruh yang maksimal terhadap ketahanan masyarakat desa. Pengaruh yang dihasilkan berupa positif dan negatif terhadap ketahanan masyarakat desa di Kelurahan Kandri. Berdasarkan indikatorindikator dalam ketahanan masyarakat desa yang dijadikan teori, telah ditemukan bahwa indikator-indikator yang menghasilkan pengaruh positif adalah sebagai berikut.

Pertama, kemampuan masyarakat dalam memperbaharui dan memelihara kawasan ekowisata telah berkembang baik. Kemampuan tersebut ditunjukkan dengan adanya (1) kesepakatan masyarakat untuk tidak diperbolehkannya mendirikan perumahan lagi di kawasan Kelurahan Kandri. Inisiatif ini melihat adanya perumahan yang terdapat di RW IV Kelurahan Kandri. (2) masyarakat meresmikan Bambu Krincing sebagai identitas flora dan Kera Jawa Ekor Panjang sebagai identitas fauna yang dimiliki Kelurahan Kandri. Peresmian ini dilakukan dengan tujuan untuk memelihara serta melestarikan identitas flora dan fauna yang dimiliki oleh Kelurahan Kandri.

Kedua, penguatan modal sosial dan ketaatan hukum dalam diri warga berkembang dengan baik. Komponen-komponen ini terlihat dengan adanya (1) meningkatnya komunikasi warga terhadap sesama dan orang lain, (2) meningkatnya rasa aman terhadap kondisi lingkungan, dan (3) menciptkana rasa aman terhadap produk yang dihasilkan.

Ketiga, kemandirian dalam diri warga di Kelurahan Kandri berkembang dengan baik di bidang ekonomi. Adanya Desa Wisata Kandri yang hidup telah membuat masyarakat menjadi lebih kreatif. Bentuk kreativitas tersebut yaitu (1) berdirinya UKM (usaha kegiatan masyarakat) bagi ibu-ibu rumah tangga, (2) mengembangkan hasil kebun dengan menjual petik di tempat, (3) bertambahnya peternak ikan, (4) menciptakan Pasar Krempyeng.

Pengaruh negatif yang timbul dalam Kelurahan Kandri yaitu menurunnya kemampuan pemuda RW III dalam memilih nilai-nilai sosial budaya dan kelembagaan sosial. Pengaruh ini merupakan salah satu dampak ekowisata pada aspek sosial yaitu pengaruh negatif diferensiasi struktur sosial dimana terjadi polarisasi antar penduduk karena proporsi pendapatan yang tidak seimbang antar kelompok masyarakat. Realita ini terjadi pada pemuda di Kelurahan Kandri. Proporsi pendapatan pemuda yang tidak seimbang memunculkan perbedaan bentuk pada pola fikir pemuda Kandri RW III.

Realita yang terjadi pada pemuda juga didukung dengan adanya dampak terhadap distribusi pengaruh dan kekuasaan. Penyebaran pengaruh dan kekuasaan terhadap kawasan ekowisata berdasarkan observasi yang telah dilakukan yaitu didominasi oleh pemuda RW I dan II. Kondisi tersebut didukung dengan tidak adanya perencanaan manajemen resiko berupa pendekatan manajemen tradisional yang dilakukan oleh minoritas pemuda Kandri. Perencanaan pendekatan manajemen tradisional untuk mengantisipasi adanya krisis tidak terdapat pada kelompok pemuda pengelola. Semua pengaruh yang muncul telah membuat kondisi pemuda mempunyai kondisi kejiwaan yang masih tidak stabil. Pemuda masih sulit mengontrol emosi, pemberontak dan pendek akal.

Faktor-faktor tersebut telah memunculkan dampak ekowisata yaitu ekowisata telah mengubah struktur internal pemuda sehingga terjadi perbedaan antara mereka yang mempunyai hubungan ekowisata dan pemuda 
yang tidak. Jadi keterkaitan dengan ekowisata menjadi salah satu pemisah atau pembeda dalam pemuda.

Pemuda dalam mengatasi permasalahan ini harus memperbaiki pola pengeloaan terutama dalam mengelola manajemen resiko. Seperti yang dijelaskan oleh Pitana dan Diarta (2009), pendekatan manajemen risiko digunakan untuk merespon krisis dan mengelola dampak krisis secara efektif dan efesien. Manajemen dapat dilakukan dengan cara merespon dan merencanakan pemulihan untuk diimplementasikan.

Umpan balik dari pengalaman yang sudah terjadi, mengidentifikasi krisis, merencanakan dan menyiapkan terjadinya krisis di masa depan menjadi langkah untuk melaksanakan manajemen risiko. Pendekatan manajemen resiko ini dapat dilakukan oleh pemuda dalam mengatasi timbulnya pengaruh negatif pada pemuda Kandri RW III dengan menggunakan metode komunikasi sebagai alat merealisasikan hasil manajemen resiko. Komunikasi yang dilakukan sebagai penyeimbang berjalannya waktu pemuda RW III karena pemuda merupakan suatu fase perkembangan dalam periode pertumbuhan biologis seseorang yang bersifat seketika, dan sekali waktu akan hilang dengan sendirinya sejalan dengan hukum biologis itu sendiri. Keanehan-keanehan masa pemuda akan menghilang dengan sendirinya dalam proses masa ke masa (Tilaar, 1974).

\section{SIMPULAN}

Dari hasil penelitian yang telah dipaparkan di atas dapat ditarik simpulan sebagai berikut.

Pertama, pemuda dalam mengelola kawasan ekowisata di Desa Wisata Kandri berperan pada indikator perjalanan ke kawasan alamiah yaitu Wisata Nyawah, Wisata Outbound, Wisata Goa Kreo, dan Wisata River Tubing. Secara keseluruhan peran pemuda belum berjalan secara maksimal dalam menyelesaikan persoalan sarana prasarana dan mengajak keseluruhan masyarakat terutama kalangan pemuda di Kelurahan Kandri, bahkan telah menimbulkan satu permasalahan baru terhadap sesama pemuda di Kelurahan Kandri.

Kedua, keberhasilan pengelolaan kawasan ekowisata di Desa Wisata Kandri yang dilakukan oleh pemuda tidak muncul begitu saja. Berbagai kendala telah ditemukan pada saat pemuda mengelola kawasan tersebut. Kendala-kendala dan upaya - upaya yang dihadapi pemuda yaitu (1) sarana dan prasaran kurang memadai. Pemuda dalam mengatasi permasalahan ini yaitu dengan memanfaatkan sarana dan prasarana yang ada (2) kurangnya pengetahuan pemuda tentang ekowisata sempat menjadi sebuah kendala, akan tetapi pemuda mampu mengatasinya dengan modal keberanian berinovasi, (3) ketidakharmonisan hubungan pokja dengan pemuda di RW III menghasilkan atraksi River Tubing difakumkan, sehingga pemuda berupaya dengan mengalihkan kefokusan kepada wisata edukasi dan tahun ini mengadakan launching kembali untuk River Tubing (4) minimnya pemuda yang ikut andil dalam pengelolaan belum mampu diselesaikan oleh pemuda pengelola.

Ketiga, faktor-faktoryang melatarbelakangi peran pemuda belum berjalan secara maksimal, karena oleh adanya 2 Pokdarwis yang menyebabkan Pokdarwis Pandanaran hanya merekrut pemuda di RW I dan II serta perekrutan pemuda yang dilakukan tidak secara keseluruhan di RW I dan II. Pola tersebut 
Sri Haryati, Armaidy Armawi, dan Muhammad Supraja -- Peran Pemuda Dalam Mengelola Kawasan Ekowisata Dan Implikasinya Terhadap Ketahanan Masyarakat Desa (Studi Tentang Pemuda Pengelola Desa Wisata Kandri, Kecamatan Gunungpati, Kota Semarang, Provinsi Jawa Tengah)

menghasilkan perekrutan yang mengikutsertakan 16 pemuda dan menyebabkan pemuda dalam mengelola kawasan ekowisata tidak berjalan secara maksimal. Pemuda dalam menangani permasalahan ini dapat melakukan manajemen resiko. Pemuda dapat menganalisis permasalahan yang ada kemudian mencarikan solusi dengan cara berkomunikasi dengan masing-masing Pokdarwis dan pemuda di RW III untuk menjalin hubungan yang lebih harmonis.

Keempat, upaya yang telah dilakukan pemuda dalam mengelola kawasan ekowisata di Desa Wisata Kandri belum memberikan pengaruh yang maksimal pada ketahanan masyarakat desa di Kelurahan Kandri. Indikator ketahanan masyarakat desa yang berhasil diwujudkan berupa (1) penguatan modal sosial dan ketaatan hukum dalam diri warga berjalan dengan baik; (2) kemampuan dalam memilih nilai-nilai sosial budaya dan kelembagaan sosial mengalami penurunan pada diri pemuda di RW III; (3) kemampuan masyarakat memperbaharui dan memelihara kawasan ekowisata mengalami peningkatan; (4) kemandirian dalam diri warga berkembang lebih baik.

Berdasarkan kendala yang dihadapi oleh pemuda Kandri dalam mengelola kawasan ekowisata di Desa Wisata Kandri, direkomendasikan hal-hal sebagai berikut.

Pertama, pemuda pengelola dapat bersinergi dengan instansi lain seperti pemerintah Kota Semarang dalam memenuhi sarana dan prasarana yang memadai.

Kedua, pemuda pengelola dapat memperdalam pengetahuan tentang ekowisata dengan bekerjasama pada universitas di Kota Semarang dan Dinas Pariwisata dan Kebudayaan Kota Semarang dengan mengadakan pelatihan tentang kepariwisataan.
Ketiga, pemuda harus membenahi kondisi intern di kelurahan Kandri dengan menjalin komunikasi yang lebih baik dengan Pokdarwis dan pemuda di RW III.

Keempat, masing-masing anggota pemuda pengelola dapat mengajak pemuda lain untuk aktif dalam mengelola kawasan ekowisata dengan melalui pendekatan emosional.

\section{DAFTAR PUSTAKA}

Anderson, Benedict. 1991, Imagened Community: Reflection On The Origin and Spread of Nationalism, Ithaca. N.Y, Cornell University Press.

Azwar, S., 2001 , Metode Penelitian, Yogyakarta, Pustaka Pelajar.

BPS Kota Semarang, 2013, Statistik Kota Semarang, Semarang, BPS

Damanik, J, dan Weber, H, F, 2006, Perencanaan Ekowisata dari Teori ke Aplikasi, Yogyakarta, Puspar UGM dan Penerbit Andi.

Hakim, Luchman, 2004, Dasar-Dasar Ekowisata, Malang, Bayumedia.

Hendryantoro, Anggun, 2014, Pemberdayaan

Masyarakat Melalui Pengembangan

Desa Wisata dan Implikasinya terhadap Ketahanan Sosial Budaya, Tesis: Program Pascasarjana Universitas Gadjah Mada. Ihsan, Moch Musoffa, 2015, Buku 8 Ketahanan Masyarakat Desa, Jakarta, Kementerian Desa, Pembangunan Daerah Tertinggal, dan Transmigrasi Republik Indonesia.

Joesoef Doed, 2014, Studi Strategi Logika Ketahanan dan Pembangunan Nasional, Jakarta, Kompas media.

Mathieson, A. dan Wall, G, 1982, Tourism: Economic, Physical and Social Impacts. Harlow, Longman. 
Mustaqim, Goris dan Tohari, 2010, Pemuda Membangun Bangsa dari Desa, Bandung, Adityo Offset.

Nugroho Iwan, 2011, Ekowisata dan Pembangunan Berkelanjutan, Yogyakarta, Pustaka Pelajar.

Nuriana, 2014, Paket Wisata Penyusunan Produk dan Penghitungan Harga, Bandung, Alfabeta.

Pitana, I G. dan Diarta I K S, 2009, Ilmu Pariwisata, Yogyakarta, Penerbit Andi.

Richardson, John I dan Martin Fluker, 2004, Understanding and Managing Tourism, Australia, Pearson Education Australia, NSW Australia.

Rosida, Idah, 2014, Partisipasi Pemuda dalam pengembangan Kawasan Ekowisata dan Implikasinya tehadap Ketahanan
Masyarakat Desa (Studi di Kawasan Ekowisata Gunung Api Purba Nglanggeran, Desa Nglanggeran, Kecamatan Patuk, Kabupaten Gunung Kidul, Provinsi Daerah Istimewa Yogyakarta, Tesis: Program Program Pascasarjana Universitas Gadjah Mada.

Soekanto, S., 1992, Sosiologi Suatu Pengantar, Jakarta, Rajawali.

Tilaar H.A.R, 1974, “Tinjauan Pedagogis mengenai Pemuda: Suatu Pendekatan Ekoforis dalam Pemuda dan Perubahan Sosial",Jakarta, LP3ES

WTO, 1980, Social and Cultural Impact of Tourist Movements. World Tourism Organization. Madris, WTO

Yudohusodo, Siswono. 1996, Semangat Baru Nasionalisme Indonesia, Jakarta: Prenhasllindo. 